\title{
User acceptance in a computer-supported collaborative learning (CSCL) environment with social network awareness (SNA) support
}

\author{
Jian-Wei Lin \\ Chien Hsin University of Science and Technology, Taiwan \\ Hao-Chiang Koong Lin \\ National University of Tainan, Taiwan
}

\begin{abstract}
Although many e-learning studies have applied the unified theory of acceptance and usage of technology (UTAUT) to investigate user acceptance, their findings have been inconsistent. One of reasons is that the user acceptance model of an e-learning system can be determined by the new information technologies (or mechanisms) the e-learning system utilises. Computer-supported collaborative learning (CSCL) with social network awareness (SNA) mechanisms has been widely adopted because it can enhance online collaborative learning effectiveness. Since new SNA mechanisms are expected to have a huge impact on user acceptance in CSCL environments, this study extends UTAUT to investigate user acceptance of an SNA CSCL environment. This study empirically evaluated the extended model by surveying 186 undergraduates, who had completed a 5-week electric commerce course in an SNA CSCL environment. The findings indicated that the SNA mechanism substantially strengthened the effect of social influence on behavioural intention to use the SNA CSCL system. Compared with other CSCL studies, the predictive power of social influence in this study was higher, while that of other determinants (i.e., performance expectancy and effort expectancy) in this study were lower. The extended model demonstrated higher explanatory power compared to models used in other CSCL studies.
\end{abstract}

\section{Background}

\section{User acceptance studies for e-learning}

Theoretical models used to investigate the determinants that affect the acceptance of information technologies include the theory of reasoned action (TRA) (Ajzen \& Fishbein, 1980) and the theory of planned behaviour (TPB) (Ajzen, 1991), as well as the technology acceptance model (TAM) (Davis, 1989). Many studies have used both the original and extended version of the theoretical models to explore students' acceptance of e-learning environments (Cheung \& Vogel, 2013; Pituch \& Lee, 2006; Roca \& Gagne, 2008). The extension of the existing model could indicate that it is insufficient for explaining some aspects of user acceptance of e-learning (Cheung \& Vogel, 2013).

Another renowned model is the unified theory of acceptance and usage of technology (UTAUT), which integrates the several theoretical models into a unified theoretical model to explain user intentions to use an information system and subsequent usage behaviour (Venkatesh, Morris, Davis, \& Davis, 2003). The four key constructs in the UTAUT are: (1) performance expectancy (PE), (2) effort expectancy (EE), (3) social influence (SI), and (4) facilitating conditions (FC). As Venkatesh et al. (2003) defined, performance expectancy (PE) is the degree to which an individual believes that using the system will help his/her performance. Effort expectancy (EE) is the ease of using a system. Social influence (SI) is the degree to which an individual perceives that it is important others believe he or she should use the new system. Facilitating conditions (FC) describe the degree to which an individual believes that an organisational and technical infrastructure exists to support use of the information system (Venkatesh et al., 2003). Additionally, behavioural intention (BI) is the degree to which an individual will adopt the information system in the future, while user behaviour (UB) is the degree to which the individual actually uses the information system (Venkatesh, 2000; Yueh, Huang, \& Chang, 2015). Notably, Khechine, Lakhak, Pascot, \& Bytha (2014) argued that the UTAUT model was proven to give a better explained variance of the intention to use technologies than previous models (i.e., TRA, TAM, and TPB). 


\section{E-learning studies based on the UTAUT model}

Table 1 shows some UTAUT-based studies for user acceptance of e-learning. Lin, Lai, and Chang (2016) divided these e-learning systems into two types: learner-centered and CSCL. Within a learner-centered elearning environment, students actively and solely complete learning tasks without peer support or collaboration (e.g., students learn independently from webpage materials). On the other hand, within a CSCL environment, students can collaboratively solve problems or acquire new knowledge through peer collaboration. Table 1 classifies these studies and lists their results of user acceptance.

Abubakar and Ahmad (2013) argued that studies that have used UTAUT to investigate technology adoption have yielded conflicting findings. According to the classification of learner-centered and CSCL, although most studies seem to have no identical results of user acceptance, some cues can still be found. Specifically, the reported impacts of PE on BI have similar conditions in both learner-centered studies and CSCL studies. That is, within the learner-centered studies, approximately half of the studies showed PE significantly affects BI, while half of those do not. The similar condition also happened within the CSCL studies. On the other hand, approximately half of the studies of learner-centered systems show SI significantly affects BI while half of those do not. In contrast, SI seems to have substantial influences on BI in most CSCL studies while seven out of eight CSCL studies show that SI significantly affects BI to use CSCL. Unlike individual (learner-centered) technology, which aims to improve individual productivity, group technology (CSCL) aims to facilitate group coordination and to support cooperation and collaboration among a group of users (Sun \& Zhang, 2006). For example, in a CSCL environment users who have adopted the technology may have the incentive to enlist other users, and they may be eager to promote the technology with peers by sharing their experience with and further offering help to potential adopters. This in turn (SI) promotes their intention to use it (BI) (Lou et al., 2000; Sun \& Zhang, 2006). Therefore, user acceptance of groupware (CSCL) differs from user acceptance of individual (learner-centered) technology due to the unique features of groupware (CSCL) (Lou, Lou, \& Strong, 2000). Individual technology is relatively personal and may be driven less by social influences compared to group technologies (Davis, 1989; Sun \& Zhang, 2006).

The inconsistencies suggest that some factors may affect the linkage between these constructs. Different technologies or system characters (e.g., learner-centered or CSCL) could be an important factor in user acceptance (Sun \& Zhang, 2006; Van Raaij \& Schepers 2008). Another example is that the common technologies (e.g., email, word processing software) are relatively easier to use than the specific technologies (e.g., database management system, telemedicine technology). Thus, perceived ease of use, which is equivalent to the UTAUT's effort expectancy, was found to have significant influences on behaviour intention (BI) for these specific technologies but not for these common technologies (Sun \& Zhang, 2006). Few studies however, have focused on the effects of different technologies on user acceptance, which is worthy of further investigation (Sun \& Zhang, 2006). 
Table 1

Studies of two type of e-learning systems (i.e., learner-centered and CSCL) that investigate user acceptance based on the UTAUT

\begin{tabular}{|c|c|c|c|c|c|c|c|}
\hline $\begin{array}{l}\text { Ssystem } \\
\text { type }\end{array}$ & Literature & Features & Surveyed on: & $\begin{array}{l}\mathrm{PE} \\
-> \\
\mathrm{BI}\end{array}$ & $\begin{array}{l}\mathrm{EE} \\
-> \\
\mathrm{BI}\end{array}$ & $\begin{array}{l}\text { SI } \\
-> \\
\mathrm{BI}\end{array}$ & $\begin{array}{l}\text { FC } \\
-> \\
\text { UB } \\
\end{array}$ \\
\hline \multirow[t]{7}{*}{$\begin{array}{l}\text { Learner- } \\
\text { centered }\end{array}$} & $\begin{array}{l}\text { Alrawashdeh, } \\
\text { Muhairat, \& } \\
\text { Alqatawnah, } \\
\text { (2012) }\end{array}$ & $\begin{array}{l}\text { Examine employee acceptance of e- } \\
\text { learning system in organisations. }\end{array}$ & $\begin{array}{l}\text { Past experience } \\
\text { (retrospect) }\end{array}$ & $\mathrm{O}$ & $\mathrm{O}$ & $\mathrm{O}$ & $\mathrm{O}$ \\
\hline & $\begin{array}{l}\text { Attuquayefio } \\
\text { \& Addo } \\
\text { (2014) } \\
\end{array}$ & $\begin{array}{l}\text { Analyse predictors of student acceptance } \\
\text { of e-learning. }\end{array}$ & $\begin{array}{l}\text { Past experience } \\
\text { (retrospect) }\end{array}$ & $\mathrm{X}$ & $\mathrm{O}$ & $\mathrm{X}$ & $\mathrm{O}$ \\
\hline & $\begin{array}{l}\text { Cheng, Yu, } \\
\text { Huang, Yu, \& } \\
\text { Yu (2011) }\end{array}$ & $\begin{array}{l}\text { Investigate mobile e-learning adoption } \\
\text { among employees. }\end{array}$ & $\begin{array}{l}\text { Past experience } \\
\text { (retrospect) }\end{array}$ & $\mathrm{X}$ & $\mathrm{X}$ & $\mathrm{O}$ & N/A \\
\hline & $\begin{array}{l}\text { Deng, Liu, \& } \\
\text { Qi, (2011) }\end{array}$ & $\begin{array}{l}\text { Identify factors in web based question- } \\
\text { answer services (WBQAS) adoption. }\end{array}$ & $\begin{array}{l}\text { Past experience } \\
\text { (retrospect) }\end{array}$ & $\mathrm{O}$ & $\mathrm{O}$ & $\bar{X}$ & $\mathrm{O}$ \\
\hline & $\begin{array}{l}\text { Gao \& Deng } \\
\text { (2012) }\end{array}$ & $\begin{array}{l}\text { Analyse factors in user acceptance of } \\
\text { mobile e-books. }\end{array}$ & $\begin{array}{l}\text { Past experience } \\
\text { (retrospect) }\end{array}$ & $\mathrm{O}$ & $\mathrm{O}$ & $\mathrm{X}$ & $\mathrm{X}$ \\
\hline & Tan (2013) & $\begin{array}{l}\text { Evaluate how students use English E- } \\
\text { learning websites. }\end{array}$ & $\begin{array}{l}\text { Past experience } \\
\text { (retrospect) }\end{array}$ & $\mathrm{O}$ & $\mathrm{O}$ & $\mathrm{O}$ & $\mathrm{O}$ \\
\hline & $\begin{array}{l}\text { Terzis \& } \\
\text { Economides } \\
(2011)\end{array}$ & $\begin{array}{l}\text { Evaluate how students use online } \\
\text { assessment. Use the constructs: perceived } \\
\text { usefulness, perceived ease of use, SI, BI. }\end{array}$ & $\begin{array}{l}\text { Subjects used } \\
\text { the online } \\
\text { assessment } \\
\text { system for } 45 \\
\text { minutes. }\end{array}$ & $\mathrm{X}$ & $\mathrm{O}$ & N/A & N/A \\
\hline \multirow[t]{8}{*}{ CSCL } & $\begin{array}{l}\text { Godin \& } \\
\text { Leader (2013) }\end{array}$ & $\begin{array}{l}\text { Identifying the factors that influence } \\
\text { electronic collaboration technology } \\
\text { acceptance (using a web-based video } \\
\text { conferencing technology, WebEx) and } \\
\text { predicted usage for virtual team } \\
\text { collaboration projects in courses. }\end{array}$ & $\begin{array}{l}\text { Subjects used } \\
\text { WebEx for } \\
\text { four-time } \\
\text { virtual } \\
\text { meetings. }\end{array}$ & $\mathrm{O}$ & $\mathrm{X}$ & $\mathrm{O}$ & $\mathrm{O}$ \\
\hline & Hsu (2012) & $\begin{array}{l}\text { Use Moodle for online discussions to } \\
\text { assist English learning. }\end{array}$ & $\begin{array}{l}\text { Past experience } \\
\text { (retrospect) }\end{array}$ & $\mathrm{O}$ & $\mathrm{O}$ & $\mathrm{O}$ & $\mathrm{X}$ \\
\hline & Ismail (2010) & $\begin{array}{l}\text { Examine user acceptance while utilising } \\
\text { Facebook amongst university students in } \\
\text { Malaysia. }\end{array}$ & $\begin{array}{l}\text { Past experience } \\
\text { (retrospect) }\end{array}$ & $\mathrm{O}$ & $\mathrm{O}$ & $\mathrm{O}$ & $\mathrm{O}$ \\
\hline & $\begin{array}{l}\text { Liu \& Huang } \\
\text { (2015) }\end{array}$ & $\begin{array}{l}\text { Examine the acceptance behaviour of } \\
\text { online synchronous collaboration (using } \\
\text { Google Doc) to support peer translation. }\end{array}$ & $\begin{array}{l}\text { Subjects co- } \\
\text { translated one } \\
\text { English article }\end{array}$ & $\mathrm{X}$ & $\mathrm{O}$ & $\mathrm{O}$ & $\mathrm{O}$ \\
\hline & $\begin{array}{l}\text { Nistor, } \\
\text { Schworm, \& } \\
\text { Werner } \\
(2012) \\
\end{array}$ & $\begin{array}{l}\text { Evaluate use of online help system. Use } \\
\text { active use intention as BI. }\end{array}$ & $\begin{array}{l}\text { Subjects used } \\
\text { the help system } \\
\text { for six months }\end{array}$ & $\mathrm{X}$ & N/A & $\mathrm{O}$ & N/A \\
\hline & $\begin{array}{l}\text { Raman \& } \\
\text { Lateh, (2015) }\end{array}$ & $\begin{array}{l}\text { Examine user acceptance while utilising } \\
\text { Facebook as a communication tool and } \\
\text { collaborative educational tool amongst } \\
\text { secondary school students in Malaysia. }\end{array}$ & $\begin{array}{l}\text { Past experience } \\
\text { (retrospect) }\end{array}$ & $\mathrm{X}$ & $\mathrm{X}$ & $\mathrm{X}$ & N/A \\
\hline & $\begin{array}{l}\text { Sumak, } \\
\text { Polancic, \& } \\
\text { Hericko, } \\
(2010)\end{array}$ & $\begin{array}{l}\text { Evaluate how students use Moodle as e- } \\
\text { learning platform. }\end{array}$ & $\begin{array}{l}\text { Past experience } \\
\text { (retrospect) }\end{array}$ & $\mathrm{O}$ & $\mathrm{X}$ & $\mathrm{O}$ & $\mathrm{O}$ \\
\hline & $\begin{array}{l}\text { Yueh et al., } \\
\text { (2015) }\end{array}$ & $\begin{array}{l}\text { Students used Wiki systems, in which } \\
\text { students were asked to discuss their team } \\
\text { projects and collaboratively develop their } \\
\text { learning and group work throughout the } \\
\text { semester. }\end{array}$ & $\begin{array}{l}\text { Subjects co- } \\
\text { worked on one } \\
\text { team project }\end{array}$ & $\mathrm{X}$ & $\mathrm{X}$ & $\mathrm{O}$ & $\mathrm{X}$ \\
\hline
\end{tabular}

Notes. O: significantly affect; X: insignificantly affect; for example, PE -> BI O means PE significantly affect BI. N/A: the article did not specify the details 


\section{CSCL with social network awareness (SNA)}

Social network awareness (SNA) is defined as the ability of a student to perceive the knowledge context of peers (i.e., the proficiency level of a specific domain and knowledge level of peers) and the social context of peers (e.g., social relationship and social interaction) within a CSCL environment (Chen \& Chang, 2014; Lin \& Lai, 2013; Lin, Mai, \& Lai, 2015; Sangin, Molinaru, Nussli, \& Dillenbourg, 2011). Many studies have asserted that a deep mutual awareness among peers enables fluid and expressive communication between individuals, resulting in a more effective coordination of ideas, opinion exchange, and actions (Lin \& Lai, 2013; Lin et al., 2015). Thus, many studies have added the SNA mechanism in a CSCL environment to unveil the knowledge context and social context of peers back to a learner. That is, CSCL with an SNA mechanism (herein, called SNA CSCL) is widely used for problem-based learning, project-based learning, or online assessment (Chen \& Chang, 2014: Kimmerle \& Cress, 2008; Lin \& Lai, 2013; Lin et al., 2015; Lin \& Tsai, 2016; Sangin et al., 2011). For example, Chen and Chang (2014) presented a SNA system capable of unveiling peers' past social interaction in a cooperative problem-based learning (PBL) environment. Lin and Lai (2013) used an SNA tool (revealing peer's social relationship, willingness degree to help, and knowledge degree) for an online formative assessment. The result shows that SNA can stimulate students to participate formative assessments and increase opportunities of knowledge sharing. Sangin et al. (2011) investigated an SNA CSCL system capable of visualising the learning partners' levels of prior knowledge, and the results showed that the system can enhance communication quality.

\section{Research aims}

The results of the UTAUT (Table 1) may also be determined by new or different technologies (mechanisms). Sun and Zhang (2006) stated that new technologies often involve factors that are rarely considered but could play an important role in user acceptance of a new technology. For example, Terzis, Moridis, and Economides (2012) added the mechanism of emotional feedback (e.g., sad and happy voices and facial expressions) to learners who had completed an assessment and further investigated whether emotional feedback significantly increased their behavioural intention to use an online assessment. Liu, Liao, and Pratt (2009) suggested that models for e-learning adoption should consider the nature of the technology since not all perceptions (e.g., factors in the UTAUT) may be salient for all technologies. The SNA CSCL is an emerging e-learning technology that has proven effective for enhancing collaborative learning in online environments. However, few studies have investigated user acceptance of an SNA CSCL environment.

In this study, students could use the SNA CSCL environment to conduct online assessments and further, ask peers for help when incorrectly answering assessment questions. The SNA mechanism supported students asking for help by providing: (1) peers' knowledge context (e.g., knowledge degree); (2) peers' social context (e.g., close friend or not, the number of help requests); and (3) learning activity context (e.g., the number of system access). To investigate user acceptance of the SNA CSCL, this study extended the UTAUT by adding the SNA determinant in the UTAUT model. Sykes, Venkatesh, and Gosain (2009) suggested that observing interaction among users seeking and providing help related to a system can reveal relationships between peer interaction and system usage, therefore study tried to understand how the SNA and online peer interactions (help seeks and responses) influence behavioural intention.

\section{Model and hypotheses}

As suggested by Raman and Lateh (2015) and Tan (2013), we did not consider the moderating effects of age and experience in UTAUT because this experiment was performed at a Taiwan University in which ages of all participants and there CSCL experiences were similar. Additionally, the moderating effects of voluntariness in UTAUT were not considered in this study because all subjects were free to use the SNA CSCL system (e.g., free to conduct online assessments and free to assist each other). Figure 1 shows the proposed model. 


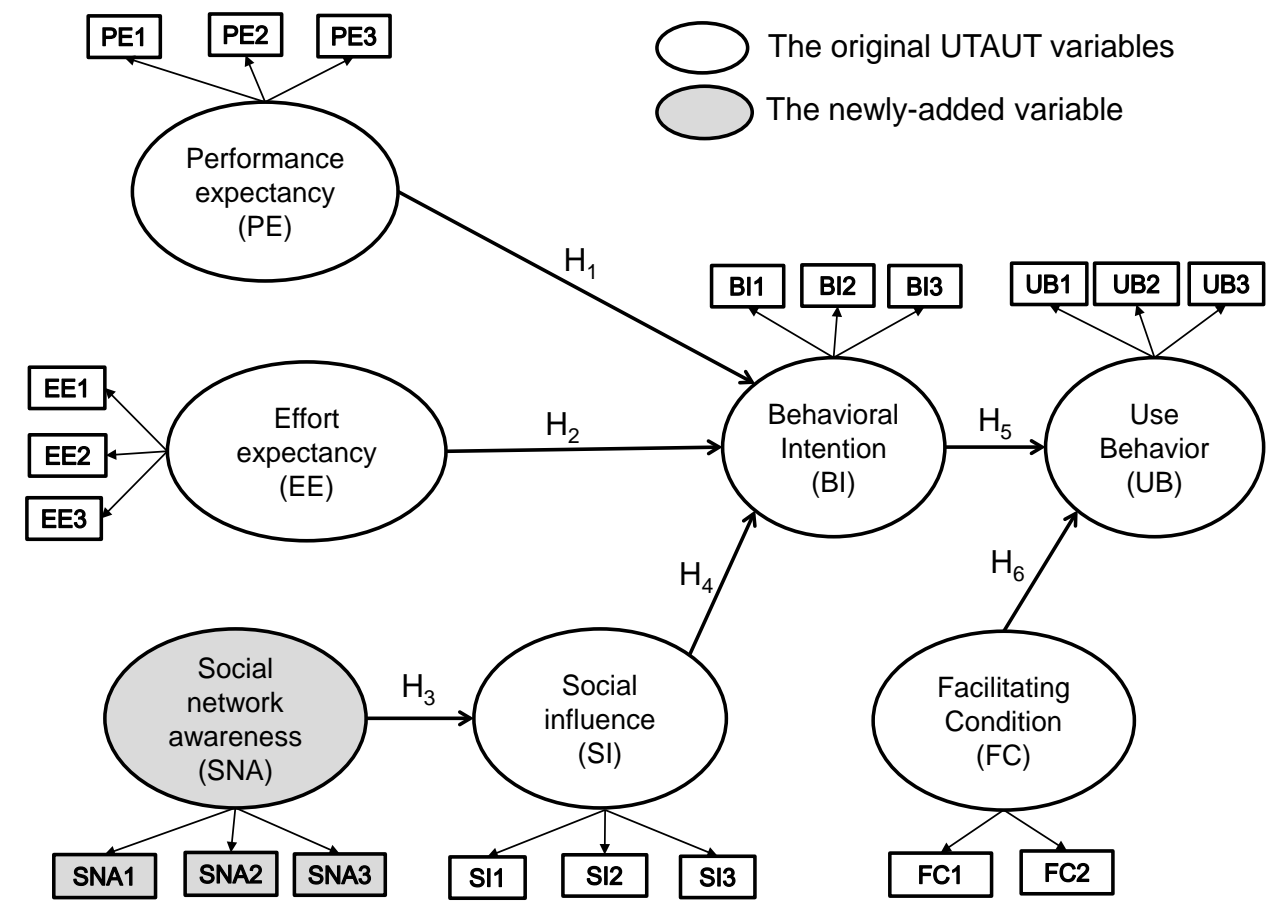

Figure1. Research model and hypotheses

\section{Effect of performance expectancy (PE)}

According to Yueh et al. (2015), PE is constructed if students perceive a CSCL tool (e.g., Wiki) as useful in completing their group term report. Hsu (2012) found that PE positively correlated to BI when using Moodle for CSCL to assist English learning. Ismail (2010) also found that PE was positively associated with BI while utilising Facebook for CSCL among university students in Malaysia. Additionally, for online assessment studies, Terzis and Economides (2011) stated that learners believed an online assessment system could improve their knowledge, comprehension, and performance for the course. The proposed SNA CSCL is an online collaborative learning environment, enabling students to conducting online assessment and assist each other when encountering problems. Thus, hypothesis 1 in this study was:

H1: Performance expectancy significantly influences behavioural intention within the SNA CSCL environment.

\section{Effect of effort expectancy (EE)}

This study defines effort expectancy as the degree to which the user believes that using the SNA CSCL would not require effort (Cheung \& Vogel, 2013). Davis (1989) assumed that a system that is perceived as simple or easy to use would be more likely to induce users' perceptions of usefulness and behavioural intentions to use it. Hsu (2012) and Ismail (2010), individually adopted Moodle and Facebook for CSCL, and both found that EE positively correlated to BI. Regarding online assessment studies, Terzis and Economides (2011) found that EE positively associated with BI. Since the proposed SNA CSCL is an online assessment environment with peer assistance, hypothesis 2 in this study was:

H2: Effort expectancy significantly influences behavioural intention within the SNA CSCL environment.

\section{Effect of the social network awareness (SNA) mechanism}

The SNA mechanism is applicable when: (1) the social and knowledge patterns of others can be identified by the student; and (2) the social and knowledge patterns of the student can be identified by others. The first means the SNA mechanism offers opportunities for the student to compare whether his/her learning 
strategies are more appropriate than others (Lin et al., 2016). Bodemer (2011) stated that SNA mechanism can be interpreted as providing tacit guidance to a learner to adjust his/her learning strategies. The second means the SNA mechanism may constrain the learning behaviour of a student because an individual presents positively when their behaviour can be observed by others in order to avoid being perceived negatively (Kimmerle \& Cress, 2008). Clearly, the SNA mechanism should substantially affect the behaviour intention of an individual through peer influence. This study further assumes that the SNA mechanism strengthens social influence on the BI of an individual.

The tradition of adding variables is common in research on UTAUT, and the approach advocated by some researchers is to extend UTAUT to CSCL (Godin \& Leader, 2013; Nistor et al., 2012; Yueh et al., 2015). Sun and Zhang (2006) stated that when the context is highly complex, additional factors are needed to capture the added complexity. In this study, the SNA, as an added variable, appeared to be a significant determinant of social influence. This might help explain the strong effect that SNA had on social influence. Thus hypothesis 3 in this study was:

H3: SNA significantly influences social influence within the SNA CSCL environment.

\section{Effect of social influence (SI)}

Yeh, Lin, and Lu (2011) argued that SI is a significant predictor of BI in technology acceptance. Furthermore, Hsu (2012), Nistor et al. (2012), and Sumak et al. (2010), who all adopted the Moodle online help system, and Moodle for CSCL, showed SI positively predicted BI. For online assessment studies, Terzis and Economides (2011) stated that students consider the opinions of their colleagues, their friends and their seniors about the perceived usefulness and the added value of online assessment system. Terzis and Economides (2011) further found that SI had a direct effect on perceived usefulness. Thus, hypothesis 4 in this study was:

H4: Social influence positively influences behavioural intentions within the SNA CSCL environment.

\section{Effect of behavioural intention (BI)}

BI reflects the motivational influences that drive an individual to perform a behaviour (Sykes et al., 2009). Ajzen (1991) also suggested that, as intention increases, the individual tries harder to perform the behaviour. In IT fields, BI to perform a behaviour has shown a strong association with use behaviour. Reported correlations between constructs approximate .50 (Sykes et al., 2009; Venkatesh et al. 2003). Thus, hypothesis 5 in this study was:

H5: Behavioural intention to use a system positively influences use behaviour.

\section{Effect of facilitating condition (FC)}

This study defines FC as support given during the online assessment (Terzis \& Economides, 2011). For example, an instructor has to be present during online assessment to attend to students' queries regarding the use of online assessment. Ismail (2010) found that FC positively associated with BI while utilising Facebook for CSCL. Sumak et al. (2010) found that FC is significantly related to use of Moodle for CSCL. Thus, hypothesis 6 in this study was:

H6: Facilitating condition positively influences use behaviour.

\section{Research methodology}

\section{The SNA CSCL system used}

The design concept of our SNA CSCL system originated from Lin and Lai (2013). The system is capable of allowing students to be aware of peer's social context; students can assist each other when encountering problems on online assessments. More specifically, the students received online assessments after completing a lesson in class. Figure 2 illustrates the system design. The students then received the results, 
but the correct answer was not provided if they failed to answer the question. For each question answered incorrectly, a student could click the corresponding button called "looking for peer assistance" to generate the candidate list. These candidates (peers) all answered the question correctly. In particular, these candidates were displayed with their specific context to provide a reference for the student (help seeker). The specific contexts include: (1) social context: social relationship (i.e., close friend or not), the number of help requests, and willingness degree to help the others; (2) knowledge context: extent of knowledge; and (3) learning activity context: the number of system accesses and the total duration of all system accesses. Additionally, the system also ranked students in terms of enthusiasm for helping peers. The design ensured that students were aware of these contexts during peer assistance. Students could then select the desired helpers from the list and send help messages. Upon a helper responding to a request, the help seeker received a notification e-mail from the system, which contained a hyperlink linking to the new response (visible only to the seeker). The student could also log into the system to check for new responses and review historical assessments.

The SNA CSCL system used the following measures to acquire the social context. Students were required to establish social relationships through the SNA CSCL system in advance (Lin \& Lai, 2013). In practice, a close friendship between two peers is established when both acknowledge the relationship (similar to the functions of friend request and acceptance in Facebook). The system also analysed participant preferences by recording participant activities as logged data (e.g., login time). Specifically, the system recorded message flow among peers, including help requests, help responses, and response rates. For each student, the response rate (defined as the willingness to help others) was calculated by dividing the number of help requests to which student responded by the number of help requests a student received.

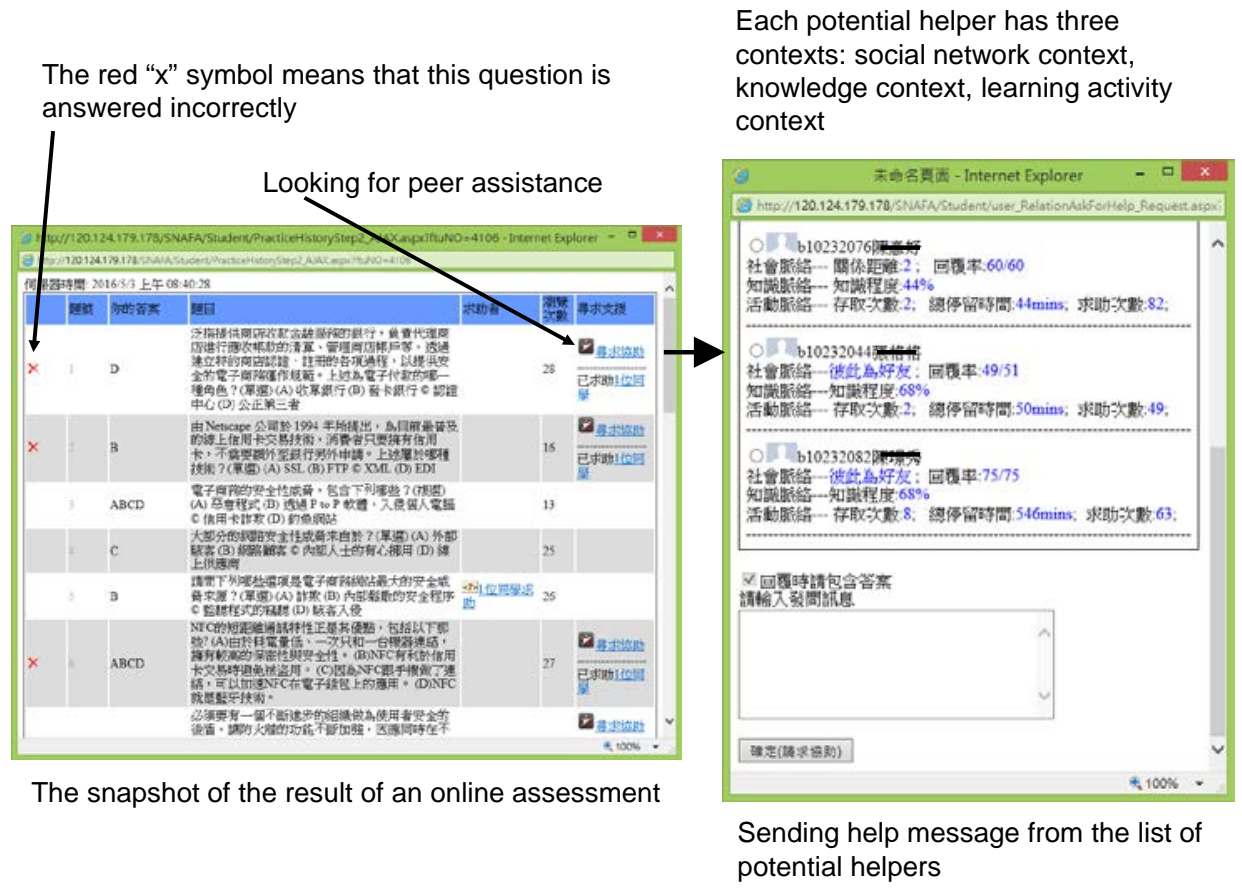

Figure 2. The SNA CSCL assessment system

\section{Participants and course}

The experiment was administered to a total of 186 students from three third-year classes of undergraduates at a Taiwan university. The students were aged between 19 and 21. The duration of the experimental subject, Electric Commerce, was a full semester, with a 2 hour per week class. The experimental subject had five learning objectives, each with a corresponding assessment. Each assessment contained around 30 multiplechoice questions based on the teaching material. This subject was a compulsory course. No participants had attempted the subject before. Prior to the experiment, students in all classes were informed that their classes would be partially delivered using some instructional methods as an experimental intervention. The students 
were also informed that data would be anonymously collected and analysed. A student had the freedom to drop his/her class allocation and take another teacher's class allocation, if preferred.

\section{Instrument}

The survey instrument used to test the research model included the seven constructs: PE, EE, SI, FC, BI, UB, and SNA. Appendix A shows the constructs, the related questionnaire items, the operational definition of each item, and their sources. For example, PE included three items which referred to Chen \& Huang (2012). All items were measured on a 5-point Likert scale ranging from 1 - strongly agree to 5 - strongly disagree.

\section{Experiment and data collection procedures}

Before the experiment, all students received 1 week of training and practice in using the SNA CSCL. Students first individually registered their personal information and then set their friendship (i.e., social relationship). We set a 1 week period for each lesson to indicate learning length expectation. Specifically, after receiving the face-to-face teaching of one lesson in 1 week, students then could take the corresponding online assessment using the SNA CSCL during that week. Meanwhile, students could request and respond to help when encountering problems on assessments, as shown in Figure 2. Since the experimental course comprised five lessons (and five corresponding assessments), all students completed the above procedures five times over 5 weeks. The experiment was designed to be long enough for students to develop learning behaviours as they became familiar with the system over an extended period of time (Lin et al., 2015). At the end of the experiment, all students completed a post-test of the survey questionnaire (Appendix A).

\section{Results}

The system logs showed that the number of help requests for the five online assessments were 86, 96, 133, 182, and 178, respectively, while the number of help responses were $66,79,116,172$, and 168, respectively. Thus, the average response rates for the five online assessments were $76 \%, 82 \%, 87 \%, 94 \%$, and $94 \%$, respectively. The number of help requests and the response rates consistently increased as the experiment progressed; particularly, the response rates reached $94 \%$ at the fifth assessment.

The sample size plays an influential role in the reliability test and in structural equation model (SEM) analysis. Bollen (1989) recommended a minimum sample size of at least 100. After removing invalid questionnaires (e.g., any questionnaire with blank answers or where all answers were the same), the number of valid questionnaires was 168, meeting the requirement of SEM minimum sample size. Of the 168 valid questionnaires, 52 were completed by male students (30.9\%) and 116 by female students (69.1\%).

This study used a two-step approach to structural equation modelling (SEM) analysis. After performing confirmatory factor analysis (CFA) to validate the measurement model, the structural model was used to test the hypotheses (Anderson \& Gerbing, 1988). The AMOS 20 software was used for the SEM analysis in this study.

\section{Measurement model}

According to Pituch and Lee (2006), each construct should be measured by at least two items. If a construct only has two items, the items should be similar to the items used by other researchers to measure the constructs. In this study, except for the facilitating condition, all other constructs consisted of three items (Appendix A). The facilitation condition was measured with two items (i.e., FC1 and FC2), which had been used in earlier studies by Attuquayefio and Addo (2014), Terzis and Economides (2011), and Terzis, Moridis, and Economides (2012). The measurement model had an acceptable fit and acceptable psychometric properties, and each item was strongly related to its respective factor (i.e., factor loading), as described below.

The measurement model was validated by means of the confirmatory factor analysis. Overall, the measurement model showed a good model-data fit: $\chi^{2} / \mathrm{df}$ ratio $=1.59$; normed fit index $(\mathrm{NFI})=0.97$; nonnormed fit index $(\mathrm{NNFI})=0.99$; comparative fit index $(\mathrm{CFI})=0.98$; and root mean square error of 
approximation $($ RMSEA $)=0.03$. All of these model-fit indices exceeded the minimum values suggested in the literature (Chow, Herold, Choo, \& Chan, 2012).

This study then examined reliability, convergent validity, and discriminant validity (Chow et al., 2012). The composite reliability (CR) and Cronbach's alpha of the constructs were used to examine reliability. As shown in Table 2, they all exceeded the acceptable criterion of 0.60 , meaning that the scales had good reliabilities (Bagozzi \& Yi, 1988).

Table 2

Descriptive statistics, average variance extracted (AVE), composite reliability (CR) and factor loading of construct measurement

\begin{tabular}{|c|c|c|c|c|c|c|c|}
\hline Variables & $M$ & $S D$ & $\begin{array}{l}\text { Factor } \\
\text { loading }\end{array}$ & $\begin{array}{l}t- \\
\text { value }\end{array}$ & AVE & CR & $\begin{array}{l}\text { Cronbach' } \\
\text { s alpha }\end{array}$ \\
\hline Performance expectancy & 4.38 & .634 & & & 0.66 & 0.85 & 0.85 \\
\hline PE1 & 4.41 & .660 & 0.90 & $9.52^{*}$ & & & \\
\hline PE2 & 4.31 & .772 & 0.76 & $7.69^{*}$ & & & \\
\hline PE3 & 4.41 & .729 & 0.78 & $8.02^{*}$ & & & \\
\hline Effort expectancy & 4.15 & .760 & & & 0.60 & 0.81 & 0.78 \\
\hline EE1 & 3.82 & 1.060 & 0.59 & $5.49^{*}$ & & & \\
\hline EE2 & 4.28 & .854 & 0.78 & $7.38^{*}$ & & & \\
\hline EE3 & 4.34 & .795 & 0.91 & $8.66^{*}$ & & & \\
\hline Social influence & 4.22 & .713 & & & 0.62 & 0.83 & 0.83 \\
\hline SI1 & 4.25 & .800 & 0.88 & $8.92^{*}$ & & & \\
\hline SI2 & 4.25 & .830 & 0.68 & $6.62^{*}$ & & & \\
\hline SI3 & 4.18 & .848 & 0.79 & $7.89^{*}$ & & & \\
\hline Facilitating condition & 4.21 & .786 & & & 0.63 & 0.83 & 0.82 \\
\hline FC1 & 4.11 & .862 & 0.81 & $7.51^{*}$ & & & \\
\hline FC2 & 4.29 & .813 & 0.77 & $7.46^{*}$ & & & \\
\hline Behavioural intention & 4.12 & .705 & & & 0.62 & 0.83 & 0.83 \\
\hline BI1 & 4.15 & .809 & 0.86 & $8.68^{*}$ & & & \\
\hline BI2 & 4.27 & .762 & 0.72 & $7.09^{*}$ & & & \\
\hline $\mathrm{BI} 3$ & 3.93 & .870 & 0.78 & $7.72^{*}$ & & & \\
\hline Use behaviour & 4.10 & .664 & & & 0.53 & 0.77 & 0.77 \\
\hline UB1 & 4.28 & .734 & 0.83 & $5.31^{*}$ & & & \\
\hline UB2 & 4.00 & .900 & 0.61 & $4.06^{*}$ & & & \\
\hline UB3 & 4.01 & .994 & 0.73 & $4.41 *$ & & & \\
\hline $\begin{array}{l}\text { Social network } \\
\text { awareness }\end{array}$ & 4.02 & .835 & & & 0.70 & 0.87 & 0.88 \\
\hline SNA1 & 4.01 & .880 & 0.92 & $10.34^{*}$ & & & \\
\hline SNA2 & 4.02 & .886 & 0.80 & $8.49^{*}$ & & & \\
\hline SNA3 & 4.04 & 1.029 & 0.79 & $8.31^{*}$ & & & \\
\hline
\end{tabular}

Unidimensionality and average variance extracted (AVE) were used as indicators of convergent validity (Bagozzi \& Yi, 1988; Chow et al., 2012). Unidimensionality was assessed in terms of factor loading and $t$ value of items (Chow et al., 2012). Table 2 shows that the factor loadings of the items of the seven factors model ranged from 0.59 to 0.92 and their $t$-values were significant at the level of $p<0.05$. All factor loading values exceeded the recommended benchmark of 0.50 (Hair, Anderson, Tatham, \& Black, 1992). All AVEs also exceeded the threshold value of 0.50 (Hair et al., 1992).

Discriminant validity was tested by comparing the square root of the AVE of each construct and its correlation coefficients with other constructs (Chow et al., 2012). Table 3 presents the results for comparison. For all the constructs, the square roots of the AVEs were larger than the correlation coefficients with other constructs, thus showing good discriminant validity (Fornell \& Larcker, 1981). In summary, all constructs in the measurement model had adequate reliability, convergent validity, and discriminant validity. 
Table 3

Square root of average variance extracted (AVE) and correlations of all constructs

\begin{tabular}{|c|c|c|c|c|c|c|c|c|}
\hline & & 1 & 2 & 3 & 4 & 5 & 6 & 7 \\
\hline 1. & Performance expectancy & 0.81 & & & & & & \\
\hline 2. & Effort expectancy & 0.51 & 0.77 & & & & & \\
\hline 3. & Social influence & 0.62 & 0.53 & 0.79 & & & & \\
\hline 4. & Facilitating condition & 0.60 & 0.50 & 0.72 & 0.78 & & & \\
\hline 5. & Behavioural intention & 0.61 & 0.51 & 0.74 & 0.69 & 0.79 & & \\
\hline 6. & Use behaviour & 0.51 & 0.48 & 0.71 & 0.68 & 0.70 & 0.73 & \\
\hline 7. & Social network awareness & 0.61 & 0.44 & 0.64 & 0.67 & 0.71 & 0.64 & 0.84 \\
\hline
\end{tabular}

Note: Square roots of AVEs are shown as diagonal elements in bold type. The diagonal elements were greater than the corresponding off-diagonal elements in the same row and column, indicating the discriminant validity.

\section{Structural model}

Hypothesis testing was performed in the context of the structural model. Figure 3 presents the properties of the causal paths, including standardised path coefficients, $p$-values, and variance explained for each equation in the hypothesised model. Not all hypotheses were supported because the path coefficients for H1, H2, and H6 were not significant at the level of $p<.001$. However, social network awareness had a significant positive effect on social influence and accounted for $64 \%$ of the variance in social influence. Social influence had a significant positive effect on use intention and accounted for $87 \%$ of the variance in behavioural intention. Behavioural intention had a significant positive effect on use behaviour and accounted for $98 \%$ of the variance in use behaviour. Social influence moderates the relationship between social network awareness and behavioural intention. Notably, within the SNA CSCL, social influence has most prominent impacts on behaviour intention (beta $=0.91$ ), compared with performance expectancy and effort expectancy.

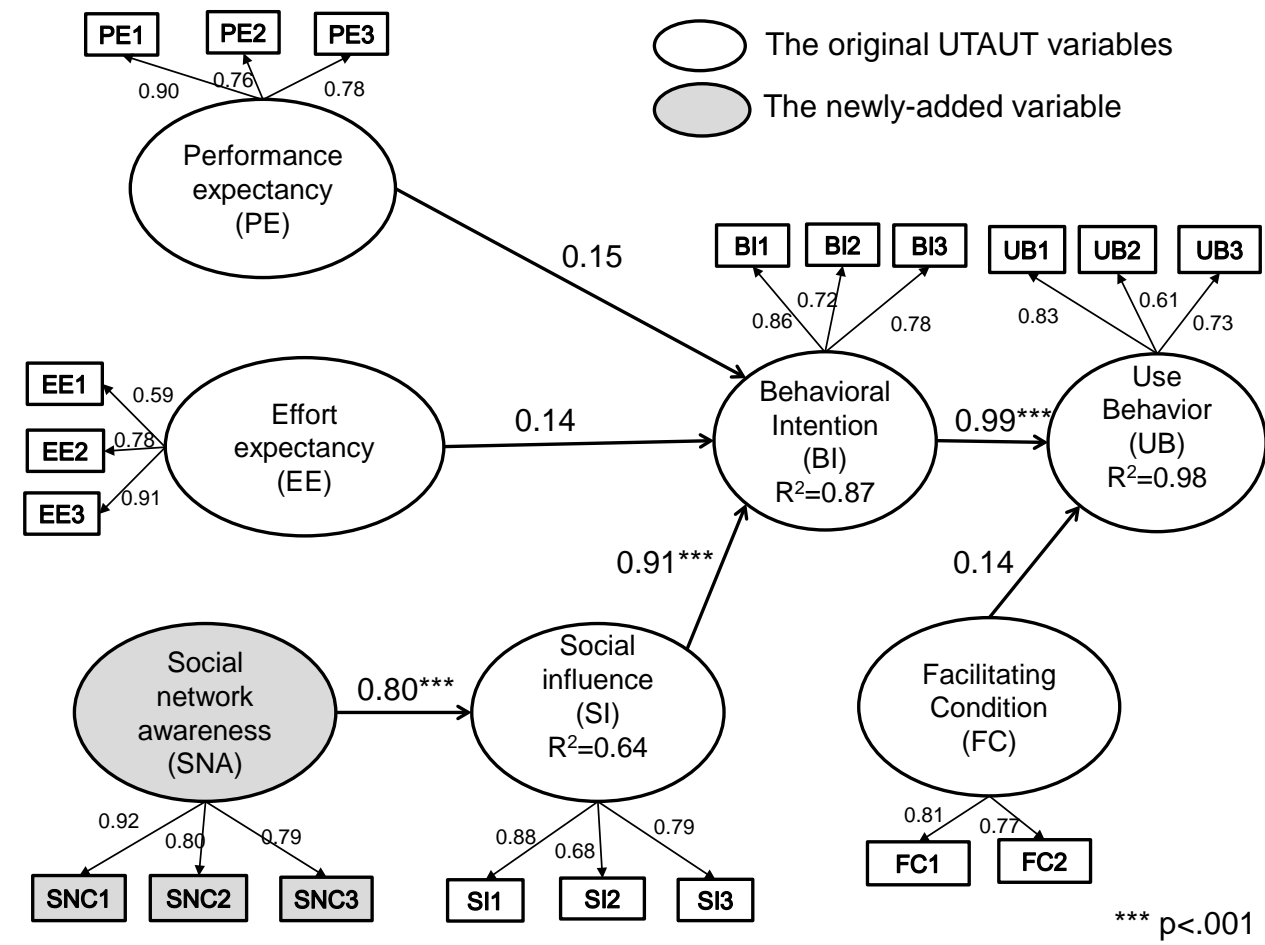

Figure 3. Results of structural equation model testing

Table 4 summarises the direct, indirect, and total effects of performance expectancy, effort expectancy, and social network awareness on social influence, behavioural intention, and use behaviour. Among all the predictor variables, behavioural intention had the strongest total effect on use behaviour (0.99), followed 
by social influence (0.90), and social network awareness (0.72). Notably, the social network awareness effect exhibited a strong direct effect on social influence (0.80), and a strong indirect effect on behavioural intention (0.73) and use behaviour (0.72). Social influence had a strong direct effect on behavioural intention (0.91) and a strong indirect effect on use behaviour (0.90).

Table 4

Square root of average variance extracted (AVE) and correlations of all constructs.

\begin{tabular}{|c|c|c|c|c|c|c|c|c|c|}
\hline & \multicolumn{3}{|c|}{ Direct effect } & \multicolumn{3}{|c|}{ Indirect effect } & \multicolumn{3}{|c|}{ Total effect } \\
\hline & $\begin{array}{l}\text { Social } \\
\text { influe } \\
\text { nce }\end{array}$ & $\begin{array}{l}\text { Behavio } \\
\text { ural } \\
\text { intentio } \\
\mathrm{n}\end{array}$ & $\begin{array}{l}\text { Use } \\
\text { behavi } \\
\text { our }\end{array}$ & $\begin{array}{l}\text { Social } \\
\text { influe } \\
\text { nce }\end{array}$ & $\begin{array}{l}\text { Behavio } \\
\text { ural } \\
\text { intentio } \\
\mathrm{n}\end{array}$ & $\begin{array}{l}\text { Use } \\
\text { behavi } \\
\text { our }\end{array}$ & $\begin{array}{l}\text { Social } \\
\text { influe } \\
\text { nce }\end{array}$ & $\begin{array}{l}\text { Behavio } \\
\text { ural } \\
\text { intentio } \\
\mathrm{n}\end{array}$ & $\begin{array}{l}\text { Use } \\
\text { behavi } \\
\text { our }\end{array}$ \\
\hline Social & & & & & & & 0.80 & 0.73 & 0.72 \\
\hline $\begin{array}{l}\text { network } \\
\text { awarene } \\
\text { ss }\end{array}$ & 0.80 & & & & 0.73 & 0.72 & & & \\
\hline $\begin{array}{l}\text { Social } \\
\text { influenc } \\
\text { e }\end{array}$ & & 0.91 & & & & 0.90 & & 0.91 & 0.90 \\
\hline $\begin{array}{l}\text { Behavio } \\
\text { ural } \\
\text { intentio } \\
n\end{array}$ & & & 0.99 & & & & & & 0.99 \\
\hline
\end{tabular}

\section{Discussion and conclusion}

\section{Factors affecting continuous SNA CSCL use intention}

The SNA CSCL is a widely used and pervasive e-learning technology that enhances online collaborative learning effectiveness. However, few studies have investigated the determinants of SNA CSCL technology adoption. Based on the UTAUT, this research identified underlying factors that affected the intentions of students to use SNA CSCL. The results showed that the extended UTAUT explained $87 \%$ of the variance in behavioural intention, which was higher (i.e., the explanatory power of the model is higher) than those of other CSCL studies (Table 1), for example, Liu and Huang (2015) (73\%), and Nistor, et al. (2012) (21\%). This high value also demonstrates that the extended UTAUT captured some of the unique contextual features of SNA CSCL.

Notably, social influence was a more accurate predictor of intention to use the SNA CSCL system (beta = 0.91) compared to other CSCL studies, for example, Liu and Huang (2015) (beta = 0.26), Nistor et al. (2012) (beta $=0.26)$, Sumak et al., (2010) (beta $=0.24)$, and Yueh et al., (2015) (beta =0.39). Additionally, although Venkatesh and Morris (2000) found that the effect of subjective norms (counterpart: social influence) on behavioural intention may weaken over time, this may be a different story within a SNA CSCL environment.

The possible reasons are as follows: (1) the CSCL environment was supported by SNAs, and (2) participants iteratively experienced collaboration processes for an extended period. The SNA tool enables: (1) a student to be aware of the social and knowledge patterns of others (as guideline references), and (2) the social and knowledge patterns of the student to be identified by others (i.e., behaviour properly to avoid negative perception). Improved mutual awareness among peers during collaborative learning causes them to reflect on their learning (Lin et al., 2016). For example, a student who notices that most requests elicit friendly responses may have higher than average willingness to request help. In contrast, an individual who notices that he/she has many requests not responded to and his/her response rate can be known by peers, might respond others' requests to avoid negative perceptions (Lin \& Lai, 2013). That is, an individual might manifest an intention to comply with the social pressure under such circumstances. Previous data showed that the number of help requests and the response rates consistently increased as the experiment progressed, 
which indicates a positive cycle of interaction among the students within the SNA CSCL. The above phenomena may explain why SNA tools significantly affect behaviour intention through social (peer) influence. When learners were iteratively immersed in assessments and peer assistance, social influence eventually become a more powerful determinant of their behaviour intention compared to findings in other CSCL studies.

Moreover, the used SNA CSCL platform was easy for students to use since they were already familiar with it at the later period of the experiment. Venkatesh et al. (2003) argued that the effect of effort expectancy is significant only during the first use, and became non-significant over periods of extended and sustained use. Inexperienced users are mainly concerned with ease of use (i.e., effort expectancy), and as experience increases, users presumably overcome concerns about ease of use (Escobar-Rodriguez \& Monge-Lozano, 2012). Cheung and Vogel (2013) further stressed that social influence (i.e., subjective norms) can reduce the power of other predictors to predict behavioural intention with passing of time. As more peers join a platform, intention becomes unconsciously directed by peers: as the effect of peer influence increases, the relationship between behavioural intention and other predictors may weaken.

\section{Implications in adopting SNA CSCL for learning practice}

One problem with formative assessment is the low rate of participation by students, which in turn downgrades learning achievements (Lin \& Lai, 2013). Thus, a teacher can apply the SNA mechanism in an online assessment system for courses to sustain students' participation rate and learning effectiveness. Through online assessments, students can identify their weaknesses and the parts of the lesson they did not understand, and further address these challenges through online peer assistance after an in-class lesson. It benefits not only current lesson learning, but also next lesson learning because without prior knowledge of preceding lessons, students typically have difficulty in understanding new concepts of subsequent lessons (Ausubel, 1968). As the course progresses and more assessment is conducted, the increasing interaction among peers could also induce sustained learning and further enhance the learning achievement (Lin \& Lai, 2013).

\section{Implications for the proposed model}

Notably, our findings reveal that while investigating the user acceptance of a new e-learning technology based on the UTAUT (or other models), the technology possibly causes new technology-related determinants to influence behaviour intention and even strengthen (or diminish) the predictive powers of the existing determinants (e.g., effort expectancy). Additionally, Lin and Tsai (2016) expressed that the SNA mechanism could significantly enhance the quantity of personal contributions and peer interactions within the CSCL project-based learning environment. This is possibly because the SNA mechanism may strengthen the impact of social influence on behavioural intention to share individual knowledge or contribute individual effort in a CSCL project-based learning environment. Thus, our model results should be applicable to a CSCL project-based learning environment with SNA support.

\section{Limitation and future work}

Wang (2011) cautioned that the e-learning environment may only temporarily affect student learning. Lin and Tsai (2016) also found that a CSCL has different time-length effects (i.e., temporary or sustainable effect) on individual with different traits. These statements are in line with Venkatesh et al. (2003) who stated that effort expectancy may be pivotal at first and become less important as time goes by. In other words, some constructs may initially have significant effects on behaviour intention and later become trivial. Thus, this study could have benefited from performing the questionnaire survey immediately after the initial use of the SNA CSCL by students, and also at more time intervals. Such findings might enhance our understanding of the causality and interrelationships between the variables at different time points (Chow et al., 2012). Finally, further studies are advised to identify additional decomposed constructs, such as computer self-efficacy (Chow et al., 2012), individual difference, or prior experience (Escobar-Rodriguez \& Monge-Lozano, 2012), each of which could further explain students' motivational perceptions and provide further insight into the determinants of SNA CSCL. 


\section{References}

Abubakar, F. M., \& Ahmad, H. B. (2013). The moderating effect of technology awareness on the relationship between UTAUT constructs and behavioural intention to use technology: A conceptual paper. Australian Journal of Business and Management Research, 3(2), 14-23. Retrieved from http://www.ajbmr.com/files/download/7789fb429e32363

Ajzen, I. (1991). The theory of planned behavior. Organizational Behavior and Human Decision Processes, 50(2), 179-211. https://doi.org/10.1016/0749-5978(91)90020-T

Ajzen, I., \& Fishbein, M. (1980). Understanding attitudes and predicting social behavior. Cliffs, NJ: Prentice-Hall.

Alrawashdeh, T. A., Muhairat, M. I., \& Alqatawnah, S. M. (2012). Factors affecting acceptance of webbased training system: using extended UTAUT and structural equation modeling. International Journal of Computer Science, Engineering and Information Technology (IJCSEIT), 2(2), 45-54. https://doi.org/10.5121/ijcseit.2012.2205

Anderson, J. C., \& Gerbing, D. W. (1988). Structural equation modeling in practice: A review and recommended two-step approach. Psychological Bulletin, 103(3), 411-423. https://doi.org/10.1037/0033-2909.103.3.411

Attuquayefio, S. N., \& Addo, H. (2014). Using the UTAUT model to analyze students' ICT adoption. International Journal of Education and Development using Information and Communication Technology, 10(3), 75-86. Retrieved from https://files.eric.ed.gov/fulltext/EJ1059042.pdf

Ausubel, D. (1968). Educational psychology: A cognitive view. New York, NY: Holt, Rinehart, and Winston.

Bagozzi, R. P., \& Yi, Y. (1988). On the evaluation of structural equation models. Journal of the Academy of Marketing Science, 16(1), 74-94. https://doi.org/10.1007/BF02723327

Bodemer, D. (2011). Tacit guidance for collaborative multimedia learning. Computers in Human Behavior, 27(3), 1079-1086. https://doi.org/10.1016/j.chb.2010.05.016

Bollen, K. A. (1989) Structural equations with latent variables. New York, NY: John Wiley \& Sons.

Chen, C. C., \& Huang, T. C. (2012). Learning in a u-Museum: Developing a context-aware ubiquitous learning environment. Computers \& Education, 59(3), 873-883. https://doi.org/10.1016/j.compedu.2012.04.003

Chen, C. M., \& Chang, C. C. (2014). Mining learning social networks for cooperative learning with appropriate learning partners in a problem-based learning environment. Interactive Learning Environments, 22(1), 97-124. https://doi.org/10.1080/10494820.2011.641677

Cheng, Y. S., Yu, T. F., Huang, C. F., Yu, C., \& Yu, C. C. (2011). The comparison of three major occupations for user acceptance of information technology: Applying the UTAUT model. iBusiness, 3(2), 147-158. https://doi.org/10.4236/ib.2011.32021

Cheung, R., \& Vogel, D. (2013). Predicting user acceptance of collaborative technologies: An extension of the technology acceptance model for e-learning. Computers \& Education, 63, 160-175. https://doi.org/10.1016/j.compedu.2012.12.003

Chow, M., Herold, D. K., Choo, T. M., \& Chan, K. (2012). Extending the technology acceptance model to explore the intention to use Second Life for enhancing healthcare education. Computers \& Education, 59(4), 1136-1144. https://doi.org/10.1016/j.compedu.2012.05.011

Davis, F. D. (1989). Perceived usefulness, perceived ease of use, and user acceptance of information technology. MIS Quarterly, 13(3), 319-340. https://doi.org/10.2307/249008

Deng, S., Liu, Y., \& Qi, Y. (2011). An empirical study on determinants of web based question-answer services adoption. Online information Review, 35(5), 789-798. https://doi.org/10.1108/14684521111176507

Escobar-Rodriguez, T., \& Monge-Lozano, P. (2012). The acceptance of Moodle technology by business administration students. Computers \& Education, 58(4), 1085-1093. https://doi.org/10.1016/j.compedu.2011.11.012

Fornell, C., \& Larcker, D. F. (1981). Evaluating structural equation models with unobservable variables and measurement errors. Journal of Marketing Research, 18(1), 39-50. https://doi.org/10.2307/3151312

Gao, T., \& Deng, Y. (2012). A study on users' acceptance behavior to mobile e-books application based on UTAUT model. Proceedings of the 2012 IEEE 3rd International Conference on Software Engineering and Service Science, China, 376-379. https://doi.org/10.1109/ICSESS.2012.6269483

Godin, J. J., \& Leader, L. F. (2013). Factors influencing the acceptance of collaboration technology 
within the context of virtual teamwork training. Paper presented at the International Conference on Educational Technologies, Malaysia. Retrieved from https://files.eric.ed.gov/fulltext/ED557177.pdf

Hair, J. T., Anderson, R. E., Tatham, R. L., \& Black, W. C. (1992). Multivariate data analysis with readings. New York, NY: Macmillan.

Hsu, H. H. (2012). The acceptance of Moodle: an empirical study based on UTAUT. Creative Education, 3(8B), 44-46. https://doi.org/10.4236/ce.2012.38B010

Ismail, S. (2010). International students' acceptance on using social networking site to support learning activities. International Journal for the Advancement of Science \& Arts, 1(2), 81-90. Retrieved from https://pdfs.semanticscholar.org/596a/2a731f4f7f16119350a3e660f0bbbd041d19.pdf

Khechine, H., Lakhal, S., Pascot, D., \& Bytha, A. (2014). UTAUT model for blended learning: The role of gender and age in the intention to use webinars. Interdisciplinary Journal of E-Learning and Learning Objects, 10(1), 33-52. Retrieved from http://www.ijello.org/Volume10/IJELLOv10p033052Khechine0876.pdf

Kimmerle, J., \& Cress, U. (2008). Group awareness and self-presentation in computer-supported information exchange. International Journal of Computer-Supported Collaborative Learning, 3(1), 85-97. https://doi.org/10.1007/s11412-007-9027-z

Lin, J. W., \& Lai, Y. C. (2013). Online formative assessments with social network awareness. Computers \& Education, 66, 40-53. https://doi.org/10.1016/j.compedu.2013.02.008

Lin, J. W., Lai, Y. C., \& Chang, L. C. (2016). Fostering self-regulated learning in a blended environment using group awareness and peer assistance as external scaffolds. Journal of Computer Assisted Learning, 32(1), 77-93. https://doi.org/10.1111/jcal.12120

Lin, J. W., Mai, L. J., \& Lai, Y. C. (2015). Peer interaction and social network analysis of online communities with the support of awareness of different contexts. International Journal of ComputerSupported Collaborative Learning, 10(2), 139-159. Retrieved from https://link.springer.com/article/10.1007/s11412-015-9212-4

Lin, J. W., \& Tsai, C. W. (2016). The impact of an online project-based learning environment with group awareness support on students with different self-regulation levels: An extended-period experiment. Computers \& Education, 99, 28-38. https://doi.org/10.1016/j.compedu.2016.04.005

Liu, S. H., Liao, H. L., \& Pratt, J. A. (2009). Impact of media richness and flow on e-learning technology acceptance. Computers \& Education, 52(3), 599-607. https://doi.org/10.1016/j.compedu.2008.11.002

Liu, Y. C., \& Huang, Y. M. (2015). Using the UTAUT model to examine the acceptance behavior of synchronous collaboration to support peer translation. JALT CALL Journal, 11(1), 77-91. Retrieved from https://files.eric.ed.gov/fulltext/EJ1107989.pdf

Lou, H., Luo, W., Strong, D., 2000. Perceived critical mass effect on groupware acceptance. European Journal of Information Systems, 9(2), 91-103. https://doi.org/10.1057/palgrave.ejis.3000358

Nistor, N., Schworm, S., \& Werner, M. (2012). Online help-seeking in communities of practice: Modeling the acceptance of conceptual artifacts. Computers \& Education, 59(2), 774-784. https://doi.org/10.1016/j.compedu.2012.03.017

Pituch, K. A., \& Lee, Y. K. (2006). The influence of system characteristics on e-learning use. Computers \& Education, 47(2), 222-244. https://doi.org/10.1016/j.compedu.2004.10.007

Raman, A., \& Lateh, H. (2015). Using facebook as a collaborative and communicative tool. Mediterranean Journal of Social Sciences, 6(1), 286-292. https://doi.org/10.5901/mjss.2015.v6n1s1p286

Roca, J. C., \& Gagné, M. (2008). Understanding e-learning continuance intention in the workplace: A self-determination theory perspective. Computers in Human Behavior, 24(4), 1585-1604. https://doi.org/10.1016/j.chb.2007.06.001

Sangin, M., Molinari, G., Nüssli, M.-A., \& Dillenbourg P. (2011). Facilitating peer knowledge modeling: Effects of a knowledge awareness tool on collaborative learning outcomes and processes. Computers in Human Behavior, 27(3), 1059-1067. https://doi.org/10.1016/j.chb.2010.05.032

Sumak, B., Polancic, G., \& Hericko, M. (2010). An empirical study of virtual learning environment adoption using UTAUT. Proceedings of 2010 IEEE Second International Conference on Mobile, Hybrid, and On-Line learning, Netherlands, 17-22. Retrieved from http://ieeexplore.ieee.org/abstract/document/5430017/

Sun, H., \& Zhang, P. (2006). The role of moderating factors in user technology acceptance. International Journal of Human-Computer Studies, 64(2), 53-78. https://doi.org/10.1016/j.ijhcs.2005.04.013

Sykes, T. A., Venkatesh, V., \& Gosain, S. (2009). Model of acceptance with peer support: a social network perspective to understand employees’ system use. MIS Quarterly, 33(2), 371-393. Retrieved from 
https://www.jstor.org/stable/20650296

Tan, P. J. B. (2013). Applying the UTAUT to understand factors affecting the use of English e-learning websites in Taiwan. Sage Open, 3(4), 1-12. Retrieved from https://journals.sagepub.com/doi/pdf/10.1177/2158244013503837

Terzis, V., \& Economides, A. A. (2011). The acceptance and use of computer based assessment. Computers \& Education, 56(4), 1032-1044. https://doi.org/10.1016/j.compedu.2010.11.017

Terzis, V., Moridis, C. N., \& Economides, A. A. (2012). The effect of emotional feedback on behavioral intention to use computer based assessment. Computers \& Education, 59(2), 710-721. https://doi.org/10.1016/j.compedu.2012.03.003

Van Raaij, E. M., \& Schepers, J. J. (2008). The acceptance and use of a virtual learning environment in China. Computers \& Education, 50(3), 838-852. https://doi.org/10.1016/j.compedu.2006.09.001

Venkatesh, V. (2000). Determinants of perceived ease of use: Integrating control, intrinsic motivation, and emotion into the technology acceptance model. Information Systems Research, 11(4), 342-365. https://doi.org/10.1287/isre.11.4.342.11872

Venkatesh, V., Morris, M. G. (2000). Why don't men ever stop to ask for directions? Gender, social influence, and their role in technology acceptance and usage behavior. MIS Quarterly, 24(1), 115-139. Retrieved from https://www.jstor.org/stable/3250981

Venkatesh, V., Morris, M. G., Davis, G. B., \& Davis, F. D. (2003). User acceptance of information technology: toward a unified view. MIS Quarterly, 27(3), 425-478. Retrieved from https://www.jstor.org/stable/30036540

Wang, T. H. (2011). Developing web-based assessment strategies for facilitating junior high school students to perform self-regulated learning in an e-Learning environment. Computers \& Education, 57(2), 1801-1812. https://doi.org/10.1016/j.compedu.2011.01.003

Yeh, N. C., Lin, J. C. C., \& Lu, H. P. (2011). The moderating effect of social roles on user behavior in virtual worlds. Online Information Review, 35(5), 747-769. Retrieved from http://www.emeraldinsight.com/doi/full/10.1108/14684521111176480

Yueh, H. P., Huang, J. Y., \& Chang, C. (2015). Exploring factors affecting students' continued Wiki use for individual and collaborative learning: An extended UTAUT perspective. Australasian Journal of Educational Technology, 31(1), 16-31. https://doi.org/10.14742/ajet.170

Corresponding author: Jian-Wei Lin, jwlin@uch.edu.tw

Australasian Journal of Educational Technology @ 2019.

Please cite as: Lin, J. W., \& Lin, H. C. K. (2019). User acceptance in a computer-supported collaborative learning (CSCL) environment with social network awareness (SNA) support. Australasian Journal of Educational Technology, 35(1), 100-115. https://doi.org/10.14742/ajet.3395 


\section{Appendix Questionnaire items}

\begin{tabular}{|c|c|c|c|}
\hline Constructs & Items & Operational definition & Sources \\
\hline \multirow[t]{3}{*}{$\begin{array}{l}\text { Performance } \\
\text { expectancy }\end{array}$} & PE1 & I find that the system improves my learning performance. & $\begin{array}{l}\text { Chen \& Huang } \\
\text { (2012) }\end{array}$ \\
\hline & PE2 & Using the system increases my learning effectiveness. & \\
\hline & PE3 & $\begin{array}{l}\text { Using the system enables me to achieve a high academic } \\
\text { performance. }\end{array}$ & \\
\hline \multirow[t]{3}{*}{$\begin{array}{l}\text { Effort } \\
\text { expectancy }\end{array}$} & EE1 & Learning to operate the system is easy for me. & $\begin{array}{l}\text { Chen \& Huang } \\
\text { (2012) }\end{array}$ \\
\hline & EE2 & I can easily become skillful at using the system. & \\
\hline & EE3 & The system has a clear and friendly user interface & \\
\hline \multirow[t]{3}{*}{$\begin{array}{l}\text { Social } \\
\text { influence }\end{array}$} & SI1 & $\begin{array}{l}\text { Classmates who are important to me affect my use of the } \\
\text { system. }\end{array}$ & $\begin{array}{l}\text { Chen \& Huang } \\
\text { (2012) }\end{array}$ \\
\hline & SI2 & $\begin{array}{l}\text { Classmates can know my learning status through the } \\
\text { SNA system and that influences my behaviour to use the } \\
\text { system. }\end{array}$ & \\
\hline & SI3 & $\begin{array}{l}\text { Classmates can know whether or not I have replied to } \\
\text { requests, which motivates me to reply to requests. }\end{array}$ & \\
\hline \multirow[t]{2}{*}{$\begin{array}{l}\text { Facilitating } \\
\text { condition }\end{array}$} & FC1 & $\begin{array}{l}\text { When I need help to use the system, someone is there to } \\
\text { help me. }\end{array}$ & $\begin{array}{l}\text { Attuquayefio \& } \\
\text { Addo (2014); } \\
\text { Terzis \& } \\
\text { Economides } \\
\text { (2011); Terzis, } \\
\text { Moridis, \& } \\
\text { Economides } \\
\text { (2012) }\end{array}$ \\
\hline & FC2 & $\begin{array}{l}\text { When I need help to learn to use the system, system's } \\
\text { help support is there to teach me. }\end{array}$ & \\
\hline \multirow[t]{3}{*}{$\begin{array}{l}\text { Behavioural } \\
\text { intention }\end{array}$} & BI1 & $\begin{array}{l}\text { I intend to use the system to improve my learning } \\
\text { effectiveness in the future. }\end{array}$ & $\begin{array}{l}\text { Tan (2013); } \\
\text { Terzis \& } \\
\text { Economides } \\
\text { (2011) }\end{array}$ \\
\hline & BI2 & $\begin{array}{l}\text { I plan to use the system to improve my academic } \\
\text { performance in the following chapters. }\end{array}$ & \\
\hline & BI3 & $\begin{array}{l}\text { In the future, I intend to observe peers' learning status } \\
\text { through the system. }\end{array}$ & \\
\hline \multirow[t]{3}{*}{$\begin{array}{l}\text { Use } \\
\text { behaviour }\end{array}$} & UB1 & $\begin{array}{l}\text { I frequently use the system for assessment before the } \\
\text { midterm. }\end{array}$ & $\begin{array}{l}\text { Cheung and } \\
\text { Vogel (2013); } \\
\text { Lin \& Lai (2013) }\end{array}$ \\
\hline & UB2 & $\begin{array}{l}\text { I often observe the learning status of peers through the } \\
\text { system before the midterm }\end{array}$ & \\
\hline & UB3 & I often review the online assessments before the midterm. & \\
\hline \multirow[t]{3}{*}{$\begin{array}{l}\text { Perception of } \\
\text { SNA }\end{array}$} & SNA1 & $\begin{array}{l}\text { This system provides information about the learning } \\
\text { context and status of peers. }\end{array}$ & Lin \& Lai (2013) \\
\hline & SNA2 & $\begin{array}{l}\text { This system provides information about the knowledge } \\
\text { level of peers. }\end{array}$ & \\
\hline & SNA3 & $\begin{array}{l}\text { This system enables me to know peers' learning } \\
\text { interaction, such as help requests and response. }\end{array}$ & \\
\hline
\end{tabular}

